Brit. F. industr. Med., 1968, 25, 283.

\title{
Immunological Aspects of Bagassosis
}

\author{
C. E. D. HEARN and VALERIE HOLFORD-STREVENS \\ From Caroni Limited (Tate and Lyle Limited), Trinidad and the Medical Research Council Clinical Immunology \\ Research Group, Institute of Diseases of the Chest, London
}

Immunological investigations of 37 patients with bagassosis, 92 unaffected bagasse workers, and I50 non-exposed controls showed that precipitins against extracts of bagasse could be demonstrated just as frequently in the unaffected and the non-exposed as in the affected. However, there was a general tendency for the precipitin levels of patients with bagassosis to fall slightly with increasing time after recovery from the clinical episode. The presence of the precipitins so far demonstrated in the sera of bagasse workers therefore appears to be of no clinical significance.

Inhalation tests with an extract of bagasse, in a group of 16 patients who had had bagassosis, produced late, systemic reactions in 15 similar to those described in farmer's lung and bird fancier's lung, so supporting the hypothesis that a similar type of hypersensitivity is the cause of bagassosis. Inhalation of extracts of Thermoactinomyces vulgaris also produced typical, late reactions in 12 out of 15 subjects, whereas extracts of Micropolyspora faeni failed to produce reactions in any of 16 subjects. The specific reactions to inhalation tests with Thermoactinomyces vulgaris were typical of a precipitin-mediated type of hypersensitivity reaction and support the view that this actinomycete may be important in the aetiology of bagassosis.

It has been shown that precipitins are produced as the result of exposure to a wide variety of vegetable dusts including sisal, hemp, cotton, bagasse, and coffee (Pepys, Longbottom, and Jenkins, 1964). Pepys, Riddell, Citron, and Clayton (1961, 1962) were the first to demonstrate the presence of precipitins, against antigens present in mouldy hay, in the sera of patients with farmer's lung. The relationship was later established (Pepys, Jenkins, Festenstein, Gregory, Lacey, and Skinner, 1963) to farmer's lung of thermophilic actinomycetes, in particular Micropolyspora faeni (Thermopolyspora polyspora) and Thermoactinomyces vulgaris (Micromonospora vulgaris).

The presence of precipitins against an extract of Micropolyspora faeni in the sera of 5 out of a group of 52 bagasse workers in Trinidad (Pepys and Jenkins, 1965) was the first serological evidence that similar antigens might be important in bagassosis, although the clinical similarity between the two conditions had been commented on by Hunter and Perry (1946).

Salvaggio, Buechner, Seabury, and Arquembourg (1966) reported the presence of precipitins against

Received for publication October 9, 1967.
I I different extracts of crude bagasse in the sera of 48 patients with bagassosis, although they were unable to demonstrate any correlation between clinical severity and the presence and number of precipitin bands.

This report describes immunological and inhalation tests, using various bagasse, fungal, and other extracts on patients with bagassosis, exposed workers, and control groups. The purpose of the investigation was to determine the precise source of the antigens concerned in the production of bagassosis.

\section{Materials and Methods}

Test Extracts Samples of bagasse from various sources, and of other vegetable dusts or fibres, were extracted with Coca's solution, dialysed, and freezedried (Pepys et al., 1964). The freeze-dried material was then dissolved in $0.9 \%$ sodium chloride, with sodium azide as a preservative for serological tests, and in Coca's solution for inhalation tests.

The following samples were extracted.

\section{Bagasse}

I. Puerto Rican: described as old dried bagasse, supplied from a mill of the Puerto Rican International Paper Company near Arecibo by Dr. Vasquez-Milan. 
2. Puerto Rican (incubated): produced by an experiment carried out at the Rothamsted Experimental Station, Harpenden, Herts, England by Dr. J. Lacey in which $50 \mathrm{~g}$. Puerto Rican bagasse (sample I) was moistened with $25 \mathrm{ml}$. sterile, distilled water and incubated at $60^{\circ} \mathrm{C}$. for eight days in an attempt to increase artificially the antigenicity of the bagasse, in the same way that the farmer's lung hay (F.L.H.) antigens increase when hay is allowed to self-heat (Festenstein, Lacey, Skinner, Jenkins, and Pepys, 1965).

3. Trinidadian: imported clean bagasse from Trinidad, supplied by Celotex Ltd., U.K.

4. Dallas Mouldy: supplied by Dr. Nicholson of Dallas, U.S.A. and collected at a factory where an outbreak of bagassosis had recently occurred.

5. Dallas Clean: also supplied by Dr. Nicholson, and also a similar 'air-dried' bagasse, but taken from another area where there had been few, if any, cases of bagassosis.

6. Jamaican (a); 7. Jamaican (b); 8. Jamaican (c); 9 . Jamaican $(d)$ : four samples of bagasse from different sugar estates in Jamaica, West Indies, supplied by Dr. L. Grant, University College of the West Indies.

Other Samples Similar extracts were also made from coffee (Kiboko dust formed from the dried outer part of the coffee berry) from East Africa, mouldy hays, and mouldy barley. Thermophilic actinomycetes (ref. nos. A.189, A.194, A.226, and A.23I) were isolated from a sample of mouldy bagasse from Trinidad by Dr. J. Lacey of the Rothamsted Experimental Station, Harpenden and cultured on nutrient agar at $40^{\circ} \mathrm{C}$. The fluid extracted from the agar plates by repeated freezing and thawing was dialysed and freeze-dried. Extracts of Micropolyspora faeni and Thermoactinomyces vulgaris (ref. no. A.64) (Pepys and Jenkins, 1965) were also used.

Sera Sera from the following groups were used for serological testing:

I. Bagassosis cases (I6), unaffected bagasse workers (69), and non-exposed controls (100) from Trinidad.

2. Bagassosis cases (7) and unaffected bagasse workers (6) from Dallas, U.S.A. (supplied by Dr. Nicholson).

3. Bagassosis cases (14) from Puerto Rico (supplied by Dr. Vasquez-Milan).

4. Bagasse workers (17) from Jamaica (collected by Mrs. Skeffery and supplied by Dr. Belle).

5. U.K. controls (50) (samples of plasma from blood bank).

Serological Tests Agar gel double-diffusion and immuno-electrophoretic tests were carried out according to methods previously described (Pepys et al., 1963), using the test extracts at concentrations of $10 \mathrm{mg} . / \mathrm{ml}$. or $20 \mathrm{mg} . / \mathrm{ml}$. for double-diffusion studies, and at $30 \mathrm{mg} . / \mathrm{ml}$. for immuno-electrophoresis. The immunoelectrophoresis slides were subsequently washed, dried, and stained with naphthalene black (Pepys and Jenkins, 1965). The regions of the immuno-electrophoretic pattern were designated $A, B$, and $C$, as for the reactions between farmer's lung sera and extracts of mouldy hay (Pepys and Jenkins, I965), with the addition of a region $D$ at the extreme anodal side of the pattern. Non
'D-line' reactions refer to precipitation patterns which do not show an arc in the $\mathrm{D}$ region. Electrophoresis of the extracts in the agar gel, with subsequent fixation by $10 \%$ acetic acid in ethanol, followed by staining for protein (naphthalene black) or mucopolysaccharide (PAS stain) (Köiw and Grönwall, I952) was also carried out.

Inhalation Tests Inhalation tests, which were all performed in Trinidad, were carried out using a Wright nebulizer and oxygen at a pressure of $20 \mathrm{lb}$./sq. in. (Williams, I963), producing droplets of particle size I-6 $\mu$ in diameter (Wright, 1958). The extracts were used at a concentration of $10 \mathrm{mg} . / \mathrm{ml}$. The clinical condition of the subject was studied, and the F.E.V.1.0 and F.V.C. were measured before the start of the inhalation and at intervals afterwards using a dry recording spirometer, the McKesson Vitalor. The inhalation of $\mathrm{I} \%$ isoprenaline sulphate was used as an index of reversible airways obstruction. Gas volumes are expressed at body temperature saturated with water vapour (B.T.P.S.). The technical difficulties in Trinidad of measuring the transfer factor unfortunately precluded its use as a field investigation.

The inhalation tests were carried out using minimal doses of the extracts initially, and then cautiously increasing the challenge if there was no reaction. In this way it is possible to evoke a specific response which is diagnostically helpful while limiting the degree of the reaction to safe levels. In the early stages of this work inhalation tests were performed because of the need for more precise diagnosis and aetiological study in the individual patient. As diagnostic criteria become more clearly established inhalation tests become less necessary. However, in bagassosis, as there is no diagnostic serological test, inhalation tests may be essential for precise diagnosis for legal purposes in occupational disease compensation.

All the subjects are numbered to permit direct comparison between the serological results and the inhalation test results shown in Table III.

\section{Results}

Serological Tests Serum samples from I6 patients from Trinidad with bagassosis were obtained at intervals between 1962 and 1967 and tested by double diffusion with bagasse extracts, the range of extracts used varying slightly. Although the numbers are small, there appears to be a general tendency for the precipitin level to fall slightly in the years following the 'attack' of bagassosis, concomitant with the avoidance of further exposure to bagasse dust. These results are summarized and compared with the incidence of precipitins in unaffected bagasse workers and nonexposed controls in Table I, where it can be seen that the two last-mentioned groups also contain reacting sera.

The first group of controls (A) was taken from 
TABLE I

Double-Diffusion Gel. Precipitin Tests: Trinidad Inhabitants

\begin{tabular}{|c|c|c|c|c|c|c|c|c|c|c|c|c|c|c|c|c|c|}
\hline \multirow{4}{*}{ Test Extract } & \multicolumn{17}{|c|}{ Sera } \\
\hline & \multicolumn{12}{|c|}{$\begin{array}{c}\text { Bagassosis Sera } \\
\text { (date of serum sample) }\end{array}$} & \multirow{2}{*}{\multicolumn{2}{|c|}{$\begin{array}{c}\text { Unaffected } \\
\text { Bagasse } \\
\text { Workers }\end{array}$}} & \multirow{2}{*}{\multicolumn{2}{|c|}{$\begin{array}{c}\text { Controls } \\
A \\
\text { (transport } \\
\text { and } \\
\text { ancillary } \\
\text { workers) }\end{array}$}} & \multirow{2}{*}{$\begin{array}{c}\text { Contr } \\
\boldsymbol{B} \\
\text { (distill } \\
\text { worke }\end{array}$} \\
\hline & \multicolumn{2}{|c|}{1962} & \multicolumn{2}{|c|}{$1963 a$} & \multicolumn{2}{|c|}{$1963 b$} & \multicolumn{2}{|c|}{$I 964$} & \multicolumn{2}{|l|}{1965} & \multicolumn{2}{|l|}{1967} & & & & & \\
\hline & No. ${ }^{1}$ & $\%$ & No. & $\%$ & No. & $\%$ & No. & $\%$ & No. & $\%$ & No. & $\%$ & No. & $\%$ & No. & $\%$ & No. \\
\hline $\begin{array}{l}\text { Bagasse } \\
\text { I. Puerto Rican } \\
\text { (a) Non D-line } \\
\text { (b) D-line } \\
\text { (c) Total } \\
\text { 3. Trinidadian } \\
\text { 4. Dallas Mouldy } \\
\text { 5. Dallas Clean } \\
\text { 6. Jamaican (a) } \\
\text { 7. Jamaican (b) } \\
\text { 8. Jamaican (c) } \\
\text { 9. Jamaican (d) } \\
\text { Coffee dust }\end{array}$ & $\begin{array}{l}\text { NT } \\
\text { NT } \\
\text { NT } \\
3 / 10 \\
\text { NT } \\
\text { NT } \\
4 / 7 \\
3 / 10 \\
0 / 10 \\
0 / 10 \\
\text { NT }\end{array}$ & $\begin{array}{l}\text { NT } \\
\text { NT } \\
\text { NT } \\
30 \\
\text { NT } \\
\text { NT } \\
57 \\
30 \\
0 \\
0 \\
\text { NT }\end{array}$ & $\begin{array}{l}\text { NT } \\
\text { NT } \\
\text { NT } \\
\text { o/3 } \\
\text { NT } \\
\text { NT } \\
2 / 3 \\
\text { NT } \\
\text { NT } \\
\text { NT } \\
\text { NT }\end{array}$ & $\begin{array}{c}\text { NT } \\
\text { NT } \\
\text { NT } \\
0 \\
\text { NT } \\
\text { NT } \\
67 \\
\text { NT } \\
\text { NT } \\
\text { NT } \\
\text { NT }\end{array}$ & $\begin{array}{l}0 / 4 \\
3 / 4 \\
3 / 4 \\
0 / 4 \\
1 / 4 \\
1 / 4 \\
1 / 4 \\
N T \\
N T \\
N T \\
3 / 4\end{array}$ & $\begin{array}{c}0 \\
75 \\
75 \\
0 \\
25 \\
25 \\
25 \\
\text { NT } \\
\text { NT } \\
\text { NT } \\
75\end{array}$ & $\begin{array}{l}2 / 7 \\
6 / 7 \\
7 / 7 \\
3 / 7 \\
3 / 7 \\
3 / 7 \\
3 / 7 \\
\text { NT } \\
\text { NT } \\
\text { NT } \\
5 / 7\end{array}$ & $\begin{array}{r}29 \\
86 \\
100 \\
43 \\
43 \\
43 \\
43 \\
\text { NT } \\
\text { NT } \\
\text { NT } \\
71\end{array}$ & $\begin{array}{c}2 / 16 \\
9 / 16 \\
10 / 16 \\
2 / 16 \\
4 / 16 \\
4 / 16 \\
2 / 16 \\
\mathrm{NT} \\
\mathrm{NT} \\
\mathrm{NT} \\
\mathrm{IO} / \mathrm{I} 6\end{array}$ & $\begin{array}{l}13 \\
56 \\
63 \\
13 \\
25 \\
25 \\
13 \\
\text { NT } \\
\text { NT } \\
\text { NT } \\
63\end{array}$ & $\begin{array}{r}1 / 16 \\
12 / 16 \\
12 / 16 \\
4 / 16 \\
1 / 16 \\
2 / 16 \\
1 / 16 \\
3 / 14 \\
2 / 14 \\
0 / 14 \\
12 / 16\end{array}$ & $\begin{array}{r}6 \\
75 \\
75 \\
25 \\
6 \\
13 \\
6 \\
21 \\
14 \\
0 \\
75\end{array}$ & $\begin{array}{r}0 / 30 \\
15 / 30 \\
15 / 30 \\
10 / 69 \\
1 / 30 \\
2 / 30 \\
21 / 69 \\
6 / 50 \\
2 / 50 \\
0 / 50 \\
16 / 30\end{array}$ & $\begin{array}{r}0 \\
50 \\
50 \\
15 \\
3 \\
7 \\
30 \\
12 \\
4 \\
0 \\
53\end{array}$ & $\begin{array}{r}2 / 50 \\
34 / 50 \\
34 / 50 \\
5 / 50 \\
2 / 50 \\
4 / 50 \\
3 / 50 \\
4 / 50 \\
1 / 50 \\
0 / 50 \\
33 / 50\end{array}$ & $\begin{array}{r}4 \\
68 \\
68 \\
10 \\
4 \\
8 \\
6 \\
8 \\
2 \\
0 \\
66\end{array}$ & $\begin{array}{r}1 / 50 \\
34 / 50 \\
35 / 50 \\
2 / 50 \\
1 / 50 \\
2 / 50 \\
5 / 50 \\
2 / 50 \\
0 / 50 \\
0 / 50 \\
34 / 50\end{array}$ \\
\hline
\end{tabular}

${ }^{1}$ No. number of positive reactions/number of sera tested

NT not tested.

workers in transport, machine shop, and other departments who were not exposed to bagasse dust. This group, however, did work within a two-mile radius of the factory and was inevitably subjected to very trivial periodic exposure to bagasse particles blown about by the wind. Therefore, a further group (B) of workers from a rum distillery, 20 miles from the sugar factory, and having no exposure whatsoever, was also examined. There was no material difference in the incidence of precipitins in the two groups.

The reactivity of the individual extracts varies greatly, as can be seen further in Table II, where the reactions of sera from subjects living outside Trinidad are shown. No relationship is apparent between the reactivity of subjects from a particular geographical locality to that of extracts derived from the same area.

TABLE II

Double Diffusion Gel Precipitin Tests:

Inhabitants of Dallas (U.S.A.), PUerto Rico, Jamaica, and U.K.

\begin{tabular}{|c|c|c|c|c|c|c|c|c|c|c|c|c|c|c|}
\hline & & & & & \multicolumn{10}{|c|}{ Sera } \\
\hline & & & & & \multicolumn{4}{|c|}{ Dallas, U.S.A. } & \multirow{2}{*}{\multicolumn{2}{|c|}{$\begin{array}{c}\text { Puerto Rico } \\
\text { Bagassosis } \\
\text { Patients }\end{array}$}} & \multirow{2}{*}{\multicolumn{2}{|c|}{$\begin{array}{c}\text { Famaica } \\
\text { Unaffected } \\
\text { Bagasse } \\
\text { Workers }\end{array}$}} & \multirow{2}{*}{\multicolumn{2}{|c|}{$\begin{array}{c}\text { U.K. } \\
\text { Normal } \\
\text { Unexposed } \\
\text { Controls }\end{array}$}} \\
\hline \multirow{2}{*}{\multicolumn{5}{|c|}{ Test Extract }} & \multicolumn{2}{|c|}{$\begin{array}{c}\text { Bagassosis } \\
\text { Patients }\end{array}$} & \multicolumn{2}{|c|}{$\begin{array}{c}\text { Unaffected } \\
\text { Bagasse } \\
\text { Workers }\end{array}$} & & & & & & \\
\hline & & & & & No. ${ }^{1}$ & $\%$ & No. & $\%$ & No. & $\%$ & No. & $\%$ & No. & $\%$ \\
\hline $\begin{array}{l}\text { Puerto Rican } \\
\text { Trinidadian } \\
\text { Dallas Mouldy } \\
\text { Dallas Clean } \\
\text { Jamaican }(a)\end{array}$ & $\begin{array}{l}\cdots \\
\cdots \\
\cdots \\
\cdots\end{array}$ & $\begin{array}{l}\cdots \\
\cdots \\
\cdots \\
\cdots\end{array}$ & $\begin{array}{l}\cdots \\
\cdots \\
\cdots \\
\cdots \\
\cdots\end{array}$ & $\begin{array}{l}\cdots \\
\cdots \\
\cdots \\
\cdots\end{array}$ & $\begin{array}{l}4 / 7 \\
I / 7 \\
I / 7 \\
I / 7 \\
N T\end{array}$ & $\begin{array}{l}57 \\
\text { I4 } \\
\text { I4 } \\
\text { I4 } \\
\text { NT }\end{array}$ & $\begin{array}{l}4 / 6 \\
0 / 6 \\
1 / 6 \\
1 / 6 \\
N T\end{array}$ & $\begin{array}{l}67 \\
0 \\
17 \\
17 \\
\text { NT }\end{array}$ & $\begin{array}{l}\text { NT } \\
\text { o/I4 } \\
\text { NT } \\
\text { NT } \\
\text { 2/I4 }\end{array}$ & $\begin{array}{l}\text { NT } \\
\text { o } \\
\text { NT } \\
\text { NT } \\
\text { I4 }\end{array}$ & $\begin{array}{l}5 / 17 \\
1 / 17 \\
0 / 17 \\
0 / 17 \\
1 / 17\end{array}$ & $\begin{array}{r}29 \\
6 \\
0 \\
0 \\
6\end{array}$ & $\begin{array}{r}30 / 50 \\
0 / 50 \\
3 / 50 \\
0 / 50 \\
0 / 50\end{array}$ & $\begin{array}{r}60 \\
0 \\
6 \\
0 \\
0\end{array}$ \\
\hline
\end{tabular}

${ }^{1}$ No. number of positive reactions/number of sera tested.

NT not tested. 
The high incidence of precipitins to the Puerto Rican bagasse extract should be noted. Further work has been done on this reaction. It has been found, by immuno-electrophoretic studies using a wide variety of sera and extracts, that the reactive antigen appears to be the same as that found in certain extracts of coffee dust, mouldy hay, and barley. On electrophoresis of these extracts an antigen reacting with a high proportion of sera from apparently normal subjects, as well as from patients suffering from a variety of diseases, has been found. This is a fast-moving, negatively charged substance and, by extension of the nomenclature in use for F.L.H. antigens, had been considered to be in the $\mathrm{D}$ region of immunoelectrophoresis tests. For convenience, this reaction will be called a 'D-line' reaction, although it is not certain that a single antigen-antibody system is responsible. It seems, however, to be due to a specific antibody rather than a non-specific precipitation, as $\gamma$ globulin prepared from a reacting serum by DEAE cellulose chromatography by the method of Levy and Sober (1960) gives the same precipitation line. Also, absorption of a serum sample with one $\mathrm{D}$-line antigen-containing extract inhibits D-line reactions to other extracts.

The bagassosis sera reacting to the Puerto Rican bagasse extract in this way therefore also react to an extract of coffee dust, and fractionation procedures have been applied to both these extracts. Many workers in the Uganda coffee industry, who have been exposed to this coffee dust, have other antibodies directed specifically against coffee extracts as well as having D-line antibodies. By saturation of the extract with ammonium sulphate the 'specific' coffee antigens are found in the precipitate whereas the D-line antigen is left in the supernatant (coffee supernatant). By further fractionation of this supernatant, using DEAE cellulose chromatography, various carbohydratecontaining fractions which did not contain D-line antigen were separated from a D-line-containing fraction. This latter fraction had a high carbohydrate content as shown by the Molisch reaction but, on electrophoresis in agar gel and subsequent fixation and drying, was not stained by protein (naphthalene black) or mucopolysaccharide (PAS) stains.

On double diffusion tests a reaction of identity was obtained between the coffee extract and the Puerto Rican bagasse extract, showing that in most sera the reaction to the Puerto Rican bagasse extract is of the D-line type. However, when testing some sera with the Puerto Rican bagasse extract, extra lines occurred in either the presence or absence of the D-line, although, as can be seen in Table I, the incidence of non $\mathrm{D}$-line reactions in the bagassosis patients was fairly low. These precipitins were shown in all the serum samples from patient 6 that were tested against the Puerto Rican bagasse extract but only in early samples from patients 2 and 15 , and were absent in sera from the other 13 bagassosis patients. Thus the high incidence of precipitins to the Puerto Rican bagasse extract is not due to an antigen present specifically in bagasse, and, if the D-line reactions are excluded, the incidence of other reactions is of the low level shown by other bagasse extracts. The $\mathrm{D}$-line reaction is hence non-specific, whereas it is possible that some of the other reactions may be specifically due to exposure to bagasse, even if not associated with the presence of actual disease.

Immuno-electrophoretic tests have been performed with these sera, but in general this test is less sensitive than double-diffusion, and most of the reactions are too weak to be seen on immunoelectrophoresis. The strong D-line type of reaction occurred with the extracts mentioned above, but only a few sera gave reactions in other regions. The serum of patient 6 , for example, reacted to negatively and positively charged antigens of Trinidadian and Jamaican ( $a$ ) bagasse extracts and to a negatively charged antigen as well as to the D-line antigen of the Puerto Rican bagasse extract, absorption with coffee removing only the D-line (Figure).

Double-diffusion tests were also performed with the actinomycete extracts on sera from those patients who were later tested by inhalation of these extracts. Sera of patients $1,6,7$, and 8 were negative but precipitins were present in the serum of patient Io to these four extracts. Serum samples from bagassosis cases were tested by double-diffusion with $M$. faeni and $T$. vulgaris at $10 \mathrm{mg} . / \mathrm{ml}$., a concentration which had previously been found suitable for farmer's lung sera. Patient 6 gave a positive reaction to $M$. faeni, but all tests with $T$. vulgaris were negative. As positive inhalation tests to $T$. vulgaris were obtained, further serological tests were performed using sera which had been concentrated three-fold by freeze-drying and subsequent addition of the required volume of water, and using sera diluted one in three. A range of concentration of the extract from I mg./ml. to $75 \mathrm{mg}$. $/ \mathrm{ml}$. was also used both in the standard double-diffusion test and in a micro test on slides using the dimensions specified for immunoelectrophoresis. Reactions with 4 out of I4 sera were obtained using the higher antigen concentrations, but these were weak diffuse lines, unlike the sharp line of a reaction between a farmer's lung serum and an extract of $M$. faeni. The reacting sera 

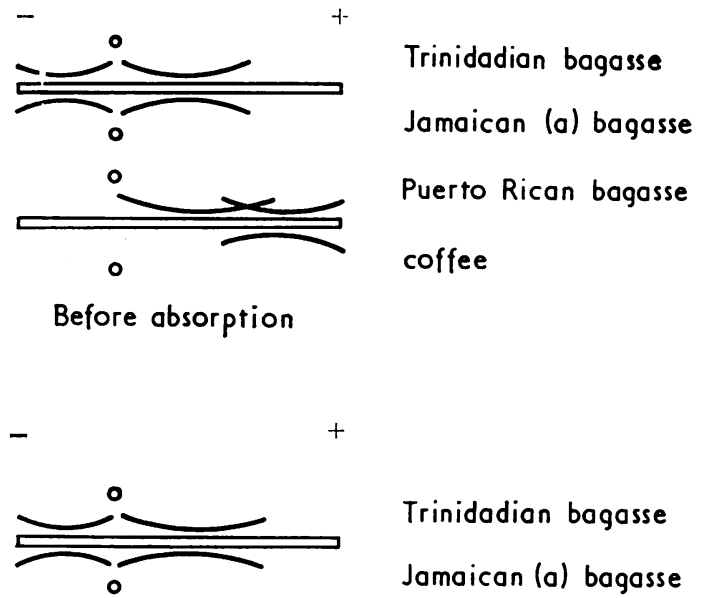

Trinidadian bagasse

Jamaican (a) bagasse

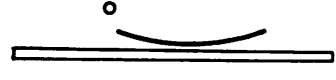

Puerto Rican bagasse

coffee

After absorption of serum with coffee extract

FIGURE. Diagram of reactions of bagassosis serum no. 6 on immuno-electrophoresis.

were from patients 5, 7, 10, and 13. However, similar reactions were also seen in 6 out of 20 normal U.K. Blood Bank plasma samples and in other control sera.

Inhalation Tests The reactions to the inhalation tests were similar to those described in farmer's lung (Williams, I963), coming on three to six hours after inhalation, reaching their maximum at about eight hours, and subsiding completely in 24 hours. A rise in temperature, accompanied by malaise and generalized aches and pains, and sometimes rigors, was associated with cough, and occasionally dyspnoea, in the more severe reactions. Similarly, the more severe reactions were associated with a fall in F.E.V.1.0 and F.V.C. which was not reversed by the inhalation of isoprenaline. In all cases the initial values for F.E.V.1.0 ${ }_{\cdot \mathbf{1}}$ and F.V.C. were normal for the racial group concerned.

Sixteen patients, all East Indians, who had recovered from bagassosis were subjected to inhalation tests with a variety of extracts. Positive reactions were produced in 15 out of 16 of these patients with the Puerto Rican bagasse extract, and in five out of eight patients tested with its artificially treated derivative. The reactions were associated with falls in F.E.V.1.0 and F.V.C. ranging from $6 \%$ to $18 \%$ (Table III), which were not reversed by the inhalation of $1 \%$ isoprenaline sulphate.
Twelve healthy controls were also subjected to inhalation tests with the Puerto Rican bagasse extract, six receiving $2 \mathrm{ml}$. and six $4 \mathrm{ml}$. of the extract. In no case was there any reaction, nor was there any alteration in their ventilatory function tests.

Extracts of Trinidadian bagasse, coffee dust (supernatant), and various actinomycetes (A.189, A.194, A.226, and A.23I) failed to produce any reactions in the subjects tested. Only very limited quantities of the actinomycete extracts were available. An initial volume of $\mathrm{I} \cdot 0 \mathrm{ml}$. was nebulized and, when no reaction occurred, either $2.0 \mathrm{ml}$. or $3.0 \mathrm{ml}$. was given, depending on the available quantity.

Inhalation tests with extracts of $M$. faeni were given to the 16 patients. In none was there any reaction, nor was there any alteration in their ventilatory function tests.

However, inhalation tests with an extract of $T$. vulgaris produced well-marked, late, systemic reactions in 12 out of 15 patients tested. Patient 6 showed a fall in F.E.V..$_{1.0}$ at the height of the reaction of $16 \%(2.921$. to 2.44 l.) and in F.V.C. of $14 \%(3.451$. to 2.981 .) of the pre-inhalation values, while patient 7 showed a fall in F.E.V.1.0 of $23 \%(2.351$. to $r \cdot 801$.) and in F.V.C. of $19 \%$ $(3.121$. to 2.511 .). Other patients showed falls in F.E.V $\cdot 1.0$ and F.V.C. ranging from $12 \%$ to $16 \%$. In all instances these falls were not reversed by the inhalation of $\mathrm{I} \%$ isoprenaline sulphate. There was no evidence of the immediate asthmatic reaction that forms part of the biphasic response described in pulmonary hypersensitivity to the grain weevil (Lunn and Hughes, 1967), and in some instances of bird fancier's lung (Hargreave, Pepys, Longbottom, and Wraith, 1966).

Twelve healthy controls were also subjected to inhalation tests with the extract of $T$. vulgaris, each receiving $2 \mathrm{ml}$. of the extract. In no case was there any reaction, nor was there any alteration in their ventilatory function tests.

\section{Discussion}

Although Salvaggio and his colleagues (1966) showed that the sera of $89.5 \%$ of 48 patients with bagassosis contained precipitins against an extract from the mouldiest specimen of bagasse, so did 12 out of $I_{7}(70.5 \%)$ unaffected bagasse workers. A higher number of patients was shown to have precipitins against mouldy $(70 \%)$ rather than fresh $(20 \%)$ bagasse, but $29 \%$ reacted with an extract of clean, compressed, finished board. They found no correlation between clinical severity and the presence and number of the precipitin bands, and 
TABLE III

INHALATION TESTS

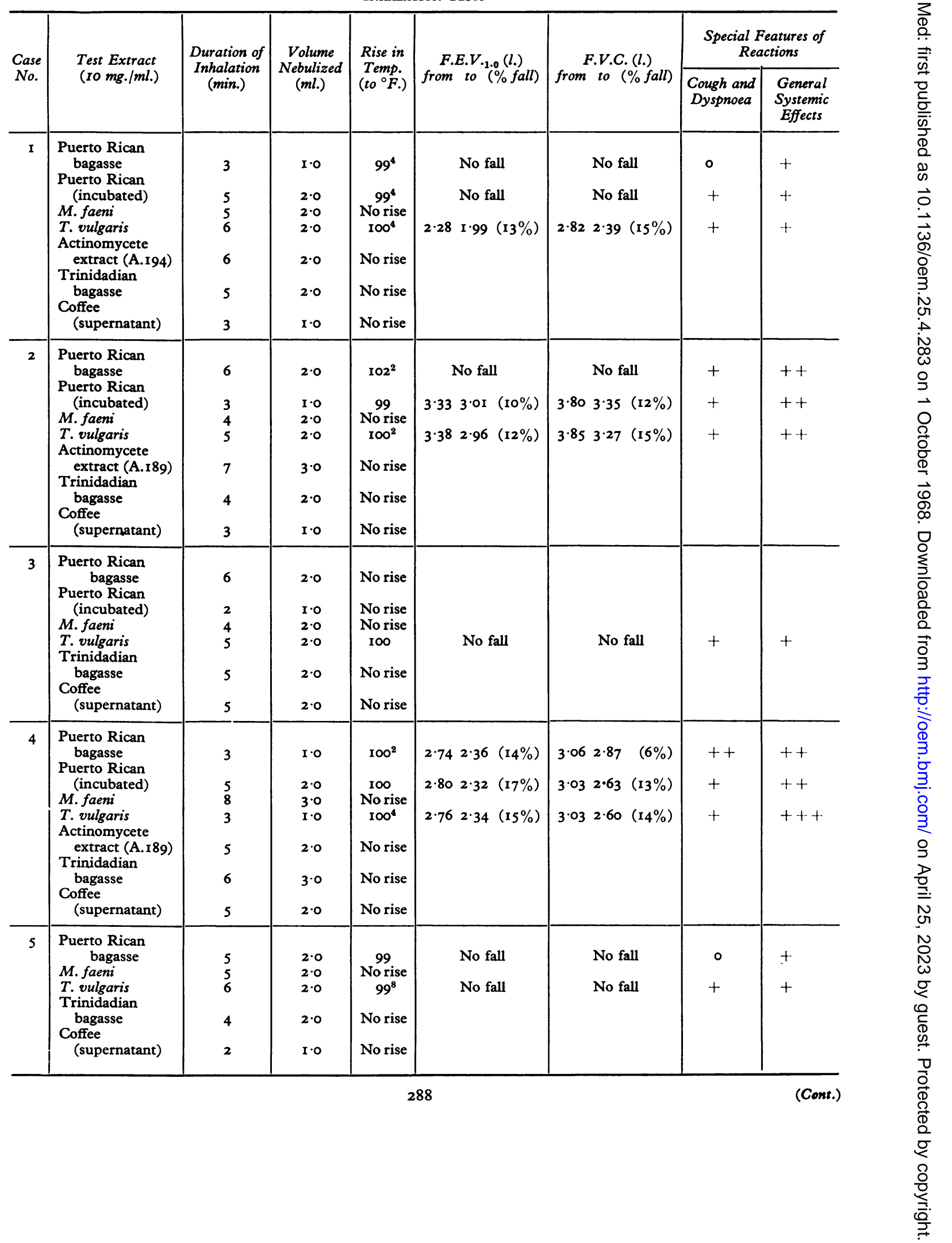


TABLE III continued

INHALATION TESTS

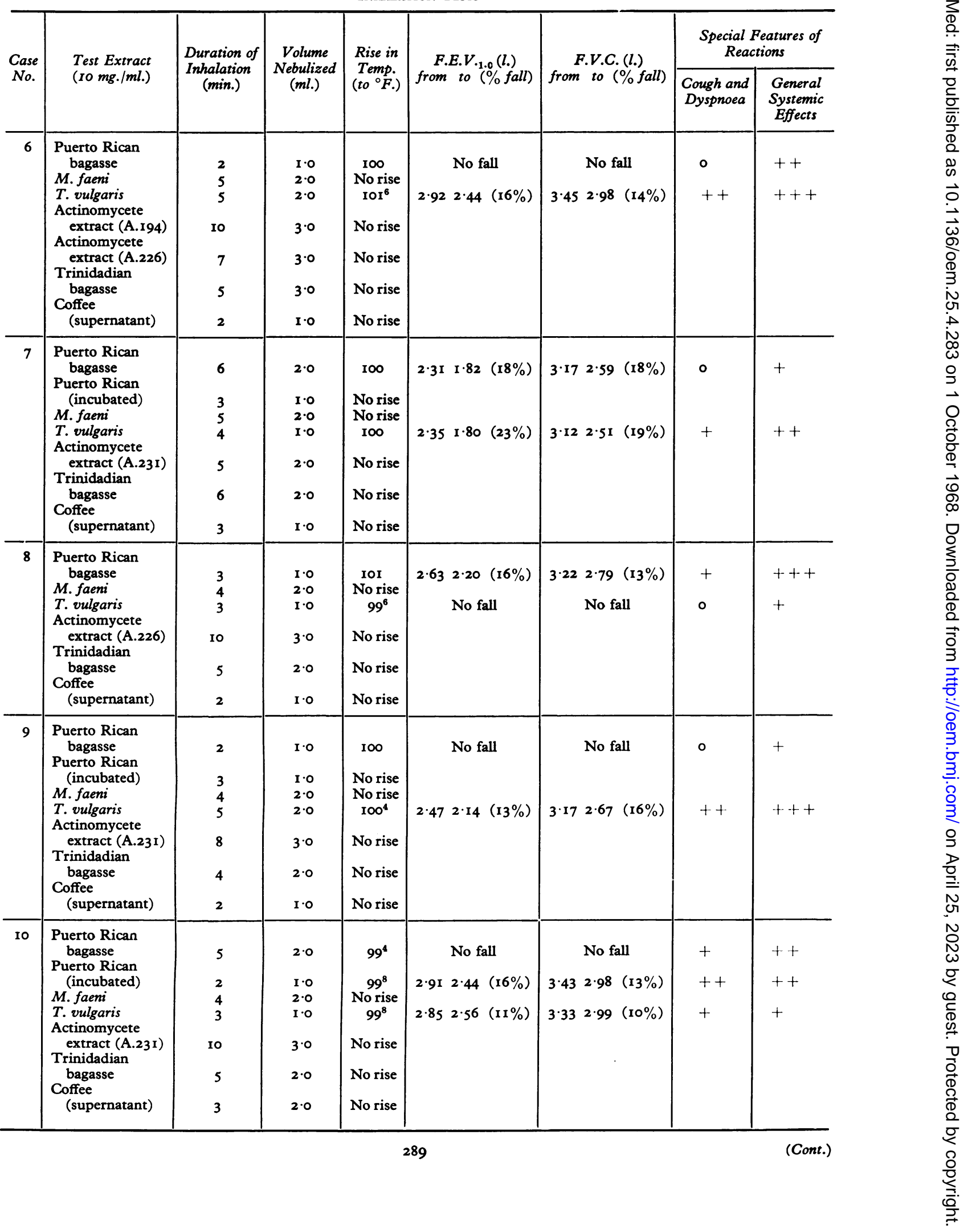


TABLE III continued

INHALATION TESTS

\begin{tabular}{|c|c|c|c|c|c|c|c|c|}
\hline \multirow{2}{*}{$\begin{array}{l}\text { Case } \\
\text { No. }\end{array}$} & \multirow{2}{*}{$\begin{array}{l}\text { Test Extract } \\
(\text { ro } \mathrm{mg} . / \mathrm{ml} .)\end{array}$} & \multirow{2}{*}{$\begin{array}{l}\text { Duration of } \\
\text { Inhalation } \\
\quad \text { (min.) }\end{array}$} & \multirow{2}{*}{ 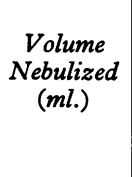 } & \multirow{2}{*}{$\begin{array}{l}\text { Rise in } \\
\text { Temp. } \\
\left(\text { to }{ }^{\circ} \mathrm{F} .\right)\end{array}$} & \multirow{2}{*}{$\begin{array}{c}\text { F.E.V.V.1.0 } \\
\text { from to }(\%) \text { fall })\end{array}$} & \multirow{2}{*}{$\begin{array}{l}\text { F.V.C. (l.) } \\
\text { from to }(\% \text { fall })\end{array}$} & \multicolumn{2}{|c|}{$\begin{array}{c}\text { Special Features of } \\
\text { Reactions }\end{array}$} \\
\hline & & & & & & & $\begin{array}{l}\text { Cough and } \\
\text { Dyspnoea }\end{array}$ & $\begin{array}{c}\text { General } \\
\text { Systemic } \\
\text { Effects }\end{array}$ \\
\hline II & $\begin{array}{l}\text { Puerto Rican } \\
\text { bagasse } \\
M . \text { faeni } \\
T . \text { vulgaris } \\
\text { Trinidadian } \\
\text { bagasse } \\
\text { Coffee } \\
\text { (supernatant) }\end{array}$ & $\begin{array}{l}3 \\
5 \\
4 \\
6 \\
3\end{array}$ & $\begin{array}{l}1 \cdot 0 \\
2 \cdot 0 \\
2 \cdot 0 \\
2 \cdot 0 \\
2 \cdot 0\end{array}$ & $\begin{array}{c}99^{2} \\
\text { No rise } \\
99^{8} \\
\text { No rise } \\
\text { No rise }\end{array}$ & $\begin{array}{l}\text { No fall } \\
\text { No fall }\end{array}$ & $\begin{array}{l}\text { No fall } \\
\text { No fall }\end{array}$ & $\begin{array}{l}+ \\
+\end{array}$ & $\begin{array}{l}+ \\
+\end{array}$ \\
\hline 12 & $\begin{array}{l}\text { Puerto Rican } \\
\quad \text { bagasse } \\
M . \text { faeni } \\
T . \text { vulgaris } \\
\text { Trinidadian } \\
\text { bagasse } \\
\text { Coffee } \\
\text { (supernatant) }\end{array}$ & $\begin{array}{l}5 \\
5 \\
4 \\
3 \\
5\end{array}$ & $\begin{array}{l}2 \cdot 0 \\
2 \cdot 0 \\
2 \cdot 0 \\
2 \cdot 0 \\
2 \cdot 0\end{array}$ & $\begin{array}{l}\text { I00 } \\
\text { No rise } \\
\text { No rise } \\
\text { No rise } \\
\text { No rise }\end{array}$ & No fall & No fall & 0 & + \\
\hline 13 & $\begin{array}{l}\text { Puerto Rican } \\
\quad \text { bagasse } \\
M . \text { faeni } \\
T . \text { vulgaris } \\
\text { Trinidadian } \\
\text { bagasse } \\
\text { Coffee } \\
\quad \text { (supernatant) }\end{array}$ & $\begin{array}{l}6 \\
6 \\
3 \\
4 \\
3\end{array}$ & $\begin{array}{l}2 \cdot 0 \\
2 \cdot 0 \\
1 \cdot 0 \\
2 \cdot 0 \\
2 \cdot 0\end{array}$ & $\begin{array}{c}99^{8} \\
\text { No rise } \\
\text { 100 } \\
\text { No rise } \\
\text { No rise }\end{array}$ & $\begin{array}{c}\text { No fall } \\
2 \cdot 34 \times \cdot 97 \quad(16 \%)\end{array}$ & $\begin{array}{c}\text { No fall } \\
2 \cdot 92 \quad 2 \cdot 58 \quad(12 \%)\end{array}$ & $\begin{array}{l}0 \\
+\end{array}$ & $\begin{array}{l}++ \\
++\end{array}$ \\
\hline I4 & $\begin{array}{l}\text { Puerto Rican } \\
\text { bagasse } \\
M . \text { faeni } \\
T . \text { vulgaris } \\
\text { Trinidadian } \\
\text { bagasse } \\
\text { Coffee } \\
\text { (supernatant) }\end{array}$ & $\begin{array}{l}3 \\
4 \\
\star \\
\\
5 \\
\\
2\end{array}$ & $\begin{array}{l}1 \cdot 0 \\
2 \cdot 0 \\
2 \cdot 0 \\
1 \cdot 0\end{array}$ & $\begin{array}{l}100 \\
\text { No rise } \\
\text { No rise } \\
\text { No rise }\end{array}$ & No fall & No fall & ++ & ++ \\
\hline 15 & $\begin{array}{l}\text { Puerto Rican } \\
\text { bagasse } \\
\text { Puerto Rican } \\
\quad \text { (incubated) } \\
M . \text { faeni } \\
T . \text { vulgaris } \\
\text { Trinidadian } \\
\text { bagasse } \\
\text { Coffee } \\
\text { (supernatant) }\end{array}$ & $\begin{array}{l}5 \\
2 \\
5 \\
8 \\
4 \\
2\end{array}$ & $\begin{array}{l}2 \cdot 0 \\
1 \cdot 0 \\
2 \cdot 0 \\
3 \cdot 0 \\
2 \cdot 0 \\
1 \cdot 0\end{array}$ & $\begin{array}{c}99 \\
99 \\
\text { No rise } \\
\text { No rise } \\
\text { No rise } \\
\text { No rise }\end{array}$ & $\begin{array}{l}\text { No fall } \\
\text { No fall }\end{array}$ & $\begin{array}{l}\text { No fall } \\
\text { No fall }\end{array}$ & $\begin{array}{l}0 \\
0\end{array}$ & $\begin{array}{l}+ \\
++\end{array}$ \\
\hline 16 & $\begin{array}{l}\text { Puerto Rican } \\
\text { bagasse } \\
M . \text { faeni } \\
T . \text { vulgaris } \\
\text { Trinidadian } \\
\text { bagasse } \\
\text { Coffee } \\
\text { (supernatant) }\end{array}$ & $\begin{array}{l}5 \\
4 \\
5 \\
3 \\
3\end{array}$ & $\begin{array}{l}2 \cdot 0 \\
2 \cdot 0 \\
2 \cdot 0 \\
2 \cdot 0 \\
2 \cdot 0\end{array}$ & $\begin{array}{l}99^{8} \\
\text { No rise } \\
\text { No rise } \\
\text { No rise } \\
\text { No rise }\end{array}$ & No fall & No fall & + & ++ \\
\hline
\end{tabular}

*Patient had left Trinidad when inhalation tests with $T$. vulgaris were being carried out.

o no reaction; + mild reaction; ++ moderate reaction; +++ marked reaction.

In all instances where there was a fall in F.E.V.1.0 and F.V.C. this was not reversed by the inhalation of $1 \%$ isoprenaline sulphate.

Gas volumes were expressed at body temperature saturated with water vapour (B.T.P.S.). 
Salvaggio, Buechner, Seabury, and Waguespack ( 1967 a) concluded that, although precipitins against mouldy bagasse were found in a significantly higher percentage of bagassosis patients than in unaffected bagasse workers, the demonstration of precipitins against mouldy bagasse is not of diagnostic significance.

Our results with a small series of patients (I6) showed that there was a general tendency for the precipitin levels to fall slightly with increasing time after recovery from the clinical episode. However, the findings of Salvaggio and his colleagues (1966) that precipitins were found only in the very occasional individual who had never known contact with bagasse dust is at variance with our results.

It is of interest that the Puerto Rican bagasse extract, which produced positive reactions in I4 out of 15 patients subjected to inhalation tests, came from the mill in Puerto Rico where the occurrence of 69 cases of bagassosis had been reported by Bayonet and Lavergne (1960).

However, although a higher proportion of patients showed precipitins against this extract than any other, the majority of the reactions were of the D-line type, the same being true of the control groups. Thirty-five out of 50 rum distillery workers living and working 20 miles away from the sugar factory showed precipitins, as did 30 out of 50 U.K. controls. Non D-line reactions were obtained in only $2 \%$ of the distillery workers and in none of the 30 unaffected bagasse workers tested. As inhalation tests using the Puerto Rican bagasse extract which contains the $\mathrm{D}$-line antigen had shown positive results in bagassosis patients, it seemed of interest to check whether precipitins to the D-line antigen were related to these clinical results. Hence the D-line antigen-containing supernatant from ammonium sulphate saturation of the coffee extract was used for further inhalation tests (coffee supernatant). It produced negative results in all subjects tested, suggesting that this particular antigenantibody system is not directly relevant to bagassosis. This is confirmed by the findings that some of the normal controls who gave negative results on inhalation testing possessed D-line antibodies as shown on serological testing.

Similarly, certain patients, especially patient 6 , had shown precipitins to several bagasse extracts, including Trinidadian bagasse, but when challenged with an inhalation test of Trinidadian bagasse no reactions occurred. Patient 6 had precipitins to $M$. faeni and patient Io to an actinomycete extract (A.23I), but negative inhalation tests were obtained with these extracts.

The significance of the presence of the precipitins so far demonstrated must, as yet, be regarded as 4 uncertain. Certainly it is true to say that their presence in bagasse workers is of no clinical significance. However, in some other circumstances the presence of precipitins is indicative of exposure to the relevant inhaled antigens and not necessarily of the presence of clinical disease. Precipitins may occur in the sera of farmers who are exposed to mouldy hay although the symptoms of farmer's lung are absent, and similarly exposure to inhaled antigens of avian origin may cause the appearance of precipitins without clinical evidence of bird fancier's lung. The majority of the patients with both these conditions have precipitins, however, and a similar precipitin reaction with an extract of Cryptostroma corticale has been shown in sera from patients suffering from maple bark disease (Emanuel, Wenzel, and Lawton, 1966; Wenzel and Emanuel, 1967). Precipitins to extracts of cotton have been found in normal subjects but with higher titres in cotton (card-room) workers and with the significantly highest titres in byssinosis patients (Massoud and Taylor, 1964). The presence of precipitins to bagasse extracts in normal subjects not exposed to this dust may similarly be due to previous exposure to a related antigen.

The production of positive reactions, of a similar type to those described in farmer's lung, to inhalation tests with the Puerto Rican bagasse extract and its artificially treated derivative is strong evidence in favour of a similar type of hypersensitivity reaction being the clinical cause of bagassosis, although the failure of extracts of $M$. faeni to produce any reactions in the 16 patients tested suggests that this particular actinomycete may not be concerned in the aetiology of bagassosis.

However, the production of well-marked late systemic reactions in 12 out of 15 patients subjected to the inhalation of $T$. vulgaris is presumptive evidence that this organism may be a causative factor in some cases of bagassosis, as it may be also in certain cases of farmer's lung (Wenzel et al., 1967). This is consistent with the findings of Salvaggio, Seabury, Buechner, and Kundur (1967b) that more than $50 \%$ of their group of bagassosis patients showed precipitins to T. vulgaris whereas precipitins were absent in sera from unaffected bagasse workers and unexposed controls. Our failure to demonstrate precipitins to this actinomycete may well be due to the level falling with the passage of time since the acute episode. It is of interest that the precipitin reactions to weevil extract in a case of pulmonary hypersensitivity to the grain weevil (Lunn and Hughes, 1967) required a two and a half times concentration of the serum for their demonstration. It may well be that, using further adaptations of this gel diffusion technique, 
a suitable system will be found giving optimal proportions for the demonstration of specific precipitins to $T$. vulgaris in this group of bagassosis patients, as has been shown in their study in the U.S.A. by Salvaggio and his colleagues (1967 b). The specific reactions to inhalation tests with $T$. vulgaris were typical of a precipitin-mediated type of hypersensitivity reaction and support the view that this actinomycete may be of importance in the aetiology of bagassosis.

We should like to thank the colleagues who furnished sera and test materials for this investigation.

Our thanks are also due to Professor J. Pepys, Medical Research Council Immunology Research Group, Institute of Diseases of the Chest, London for his help and guidance, and to Professor R. S. F. Schilling and his colleagues of the Department of Occupational Health and Applied Physiology, London School of Hygiene and Tropical Medicine for their advice and criticism.

Finally, we must record our indebtedness to the I6 patients who co-operated so willingly throughout the course of this investigation, and to the other workers who acted as controls.

\section{REFERENCES}

Bayonet, N., and Lavergne, R. (1960). Respiratory disease of bagasse workers: A clinical analysis of 69 cases. Industr. Med. Surg., 29, 519-522.

Emanuel, D. A., Wenzel, F. J., and Lawton, B. R. (1966). Pneumonitis due to Cryptostroma corticale (Maple-bark disease). New Engl. F. Med., 274, I4I3-14I8.

Festenstein, G. N., Lacey, J., Skinner, F. A., Jenkins, P. A., and Pepys, J. (1965). Self-heating of hay and grain in Dewar flasks and the development of farmer's lung antigens. F. gen. Microbiol., 41, 389-407.

Hargreave, F. E., Pepys, J., Longbottom, J. L., and Wraith, D. G. (I966). Bird breeder's (fancier's) lung. Lancet, I, 445-449.

Hunter, D., and Perry, K.M.A. (1946). Bronchiolitis resulting from the handling of bagasse. Brit. f. industr. Med., 3, 64-74.

Köiw, E., and Grönwall, A. (1952). Staining of protein-bound carbohydrates after electrophoresis of serum on filter paper. Scand. F. clin. Lab. Invest., 4, 244-246.
Levy, H. B., and Sober, H. A. (1960). A simple chromatographic method for preparation of gamma globulin. Proc. Soc. exp. Biol. (N.Y.), 103, 250-252.

Lunn, J. A., and Hughes, D. T. D. (1967). Pulmonary hypersensitivity to the grain weevil. Brit. $\mathcal{F}$. industr. Med., 24, I58-16I.

Massoud, A., and Taylor, G. (1964). Byssinosis: antibody to cotton antigens in normal subjects and in cotton cardroom workers. Lancet, 2, 607-6ro.

Pepys, J., Riddell, R. W., Citron, K. M., and Clayton, Y. M. (I96I). Precipitins against extracts of hay and fungi in the serum of patients with farmer's lung. Acta allerg. (Kbh.), 16, 76-77.

$\longrightarrow,-,-$, and - (1962). Precipitins against extracts of hay and moulds in the serum of patients with farmer's lung, aspergillosis, asthma, and sarcoidosis. Thorax, 17, 366-374.

-, Jenkins, P. A., Festenstein, G. N., Gregory, P. H., Lacey, M. E., and Skinner, F. A. (1963). Farmer's lung. Thermophilic actinomycetes as a source of 'farmer's lung hay' antigen. Lancet, 2, 607-6I I.

-, and Jenkins, P. A. (1965). Precipitin (F.L.H.) test in farmer's lung. Thorax, 20, $21-35$.

- Longbottom, J. L., and Jenkins, P. A. (1964). Vegetable dust pneumoconioses. Immunologic responses to vegetable dusts and their flora. Amer. Rev. resp. Dis., 89, 842-858.

Salvaggio, J. E., Buechner, H. A., Seabury, J. H., and Arquembourg, P. (1966). Bagassosis: I. Precipitins against extracts of crude bagasse in the serum of patients. Ann. intern. Med., 64, 748-758.

,-- , and Waguespack, H. (1967a). Bagassosis : II. Skin reactivity to crude bagasse extracts and atopic status of patients. Int. Arch. Allergy, 31, I-13.

—, Seabury, J. H., Buechner, H. A., and Kundur, V. G. (1967b). Bagassosis: demonstration of precipitins against extracts of thermophilic actinomycetes in the sera of affected individuals. $\mathcal{F}$. Allergy, 39, 106 (abstract).

Wenzel, F. J., and Emanuel, D. A. (1967). The epidemiology of maple bark disease. Arch. environm. Hlth, 14, 385-389.

- - - and Lawton, B. R. (1967). Pneumonitis due to Micromonospora vulgaris. Amer. Rev. resp. Dis., 95, $652-655$.

Williams, J. V. (1963). Inhalation and skin tests with extracts of hay and fungi in patients with farmer's lung. Thorax, 18, 182-196.

Wright, B. M. (1958). A new nebuliser. Lancet, 2, 24-25. 